\title{
A Study on The Male and Female Genital Structures of Two Cortodera Species (Coleoptera: Cerambycidae) From Turkey ${ }^{1}$
}

\author{
Türkiye'den Iki Cortodera (Coleoptera: Cerambycidae) Türünün \\ Erkek ve Dişi Genital Yapıları Üzerine Bir Çalışma
}

\author{
Research Article
}

Burcu Şabanoğlu²*, Osman Sert

'This study is a part of first author's PhD Thesis carrying out in Hacettepe University, Institute of Sciences, Biology Department. ${ }^{2}$ Hacettepe University, Faculty of Science, Department of Biology, Ankara, Turkey.

${ }^{3}$ Hacettepe University, Faculty of Science, Department of Biology, Ankara, Turkey.

\section{A B S TR ACT}

\begin{abstract}
n this study, the male and female genital structures of Cortodera flavimana (Waltl, 1838) and the female genital structures of Cortodera colchica Reitter, 1890 were examined. Three females of $C$. colchica were collected in the city of Ankara, Konya and Sivas, in June 14, 2011, June 6, 2009 and June 22, 2011. Five males and two females of $C$. flavimana were collected in the city of Eskişehir, Yozgat, Çankırı and Sivas, in June 16, 2010, May 26, 2011, June 4, 2011 and June 22, 2011. Description and drawings of male and female genital structures of $C$. flavimana and the female genital structures of $C$. colchica are given in details for the first time.
\end{abstract}

\section{Key Words}

Male, female, genitalia, Cortodera, Cerambycidae, Turkey.

\section{ÖZET}

\begin{abstract}
Sunulan bu çalışma, Cortodera flavimana (Waltl, 1838)'nın dişi ve erkek genital yapıları ve Cortodera colchica Reitter, 1890'nın dişi genital yapısı incelenmiştir. C. colchica'ya ait üç dişi 14 Haziran 2011, 6 Haziran 2009 ve 22 Haziran 2011'de Ankara, Konya ve Sivas'tan toplanmıştır. C. flavimana'ya ait 5 erkek ve 2 dişi 16 Haziran 2010, 26 Mayıs 2011, 4 Haziran 2011 ve 22 Haziran 2011'de Eskişehir, Yozgat, Çankırı ve Sivas'tan toplanmıştır. C. flavimana türünün erkek ve dişi, C. colchica türünün dişi genital yapılarının tanımlamaları ve çizimleri ilk kez detaylı olarak verilmiştir.
\end{abstract}

\section{Anahtar Kelimeler}

Erkek, dişi, genitalya, Cortodera, Cerambycidae, Türkiye.

Article History: Received: Oct 20, 2015; Revised: Nov 23, 2015; Accepted: Nov 28, 2015; Available Online: Dec $30,2015$. DOI: $10.15671 /$ HJBC.20154315986

Correspondence to: B. Şabanoğlu, Hacettepe University, Faculty of Science, Department of Biology, Ankara, Turkey. 


\section{INTRODUCTION}

Tre he female and male genital structures, which are often used in distinguishing insects at the species level, have not been described and drawn for Cortodera flavimana (Waltl, 1838) and Cortodera colchica Reitter, 1890. C. flavimana was erected by Walt at 1838 . This species are known to found in Palearctic region. While the Cerambycidae species were examined (at) a lot of studies (Ehara, 1956; Önalp, 1988, 1990, 1991; Sama, 1988; Hernandez, 1992; Hernandez and Ortuno, 1997; Hubweber and Schmitt, 2010) neither the male and the female genital structures of $C$. flavimana nor the female genital structures of $C$. colchica had been described. Herein, the male genitalia and spermathecae of C. flavimana and the spermathecae of $C$. colchica were described and drawn in this study and it is the first time at world of science.

\section{Methods}

Three females of $C$. colchica were collected in the city of Ankara, Konya and Sivas, in June 14, 2011, June 6, 2009 and June 22, 2011. Five males and two females of $C$. flavimana were collected in the city of Eskişehir, Yozgat, Çankırı and Sivas, in June 16, 2010, May 26, 2011, June 4, 2011 and June 22,2011 . The male and female genitalia were pulled out using standart methods; figure were drawn with a steoroscopic binocular microscope (LeicaMz 16A). Nomenclature follows Tuxen (1970) and Ehara (1956).

\section{RESULTS and DISCUSSION}

\section{Cortodera flavimana (Waltl, 1838)}

Male genitalia (in ventral view, Figure 1a, b): Lenght 1,52-1,54 mm, chitinous; median lobe is bow like shape from basal to medio-distal, from medio-distal to apical direction almost parallel, its apical narrows like triangular shape, median oriface with blunt bulge, internal edge of median foramen is pointed; tegmen without roof; lateral lobes are separated and crosswise location vis a vis, anterior part with yellowish orange hairs; ring part is "V" shaped from basal to medial, like square shape from medial to apical, with strong projection at inner anterior part.

Lateral view (Figure 1c): Median lob is strongly curved like a bow shape.
Spermatheca(Figure 2a): Spermatheca is 0.25 $\mathrm{mm}$, brownish orange, chitinous, its shape like " $C$ " letter with almost equal lenght arms, norrows from distal to apikal.

\section{Distributions}

World: Austria, Bulgaria, Hungary, Macedonia, Romania, Serbia, Slovakia, Switzerland and Turkey (Löbl and Smetana, 2010).

Turkey: Adana, Afyon, Aksaray, Ankara, Antalya, Artvin, Bayburt, Bolu, Bursa, Çanakkale, Erzurum, Gümüşhane, iç̧el, Isparta, İzmir, Kahramanmaraş, Kars, Kastamonu, Kayseri, Kocaeli, Konya, Niğde, Rize, Samsun, Sinop, Sivas, Tokat, Yozgat (Özdikmen, 2011)

\section{Cortodera colchica Reitter, 1890}

Spermatheca (Figure 2b): Spermatheca is $0.3 \mathrm{~mm}$, brownish yellow, chitinous, its arms is not equal lenght, curved strongly at anterior, slightly at posterior part, norrows from distal to apical.

\section{Distributions}

World: Armenia, Azerbaijan, Georgia, Iran, Lebonan, Russia, SyriaandTurkey (Löbl and Smetana, 2010).

Turkey: Adana, Adıyaman, Aksaray, Ankara, Antalya, Artvin, Bingöl, Burdur, Bayburt, Erzurum, Hakkari, Içel, Kars, Kayseri, Konya and Sivas (Özdikmen, 2011).

Male genital organ structure belonging to $C$. flavimana studied in this study was compared with male genitalia of C. humeralis (Adlbauer, 1988). These two species have distinctive differences in the sense of median lob and lateral lob. While in $C$. flavimana analyzed in this study, median lob run parallel until distal and gets narrow close towards apical; it gets distinctively narrow from mediodistal in $C$. humeralis. While inner side of median foramen is sharp and runs towards medio-distal in C. flavimana, it is butt and runs towards distal in $C$. humeralis; which forms an important difference. Median arms could not be compared since they were not drawn in $\mathrm{C}$. humeralis. When lateral lobs are considered; it is seen in C. flavimana that they have the same width from basal to apical and are get close to each other in apical and bend. In spite 


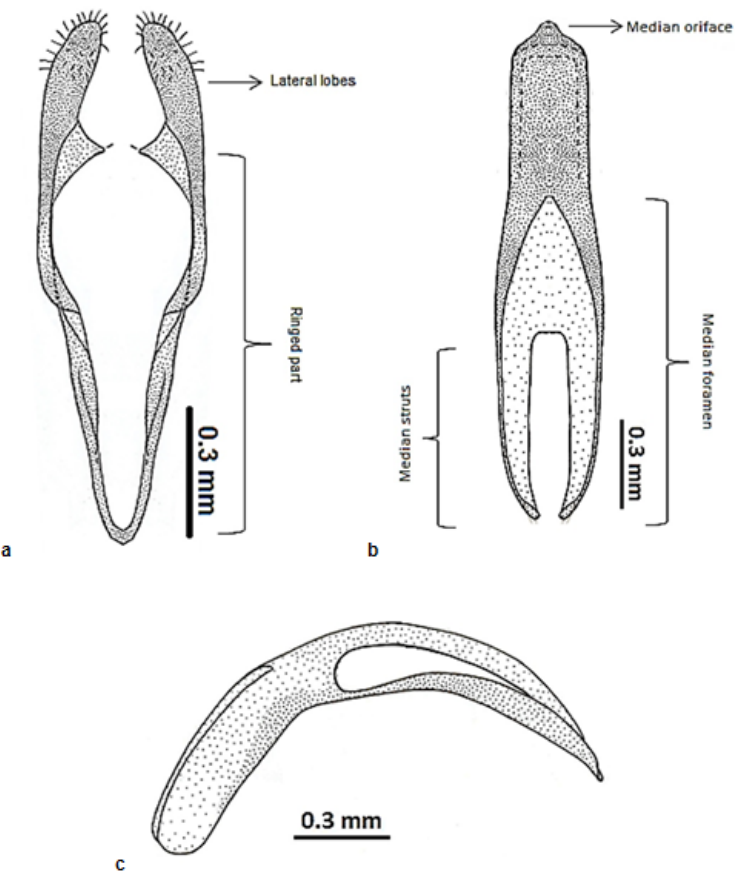

Figure 1. C. flavimana a) Paramer (ventral) b) Median Lob (ventral) c) Median lob (lateral).

a

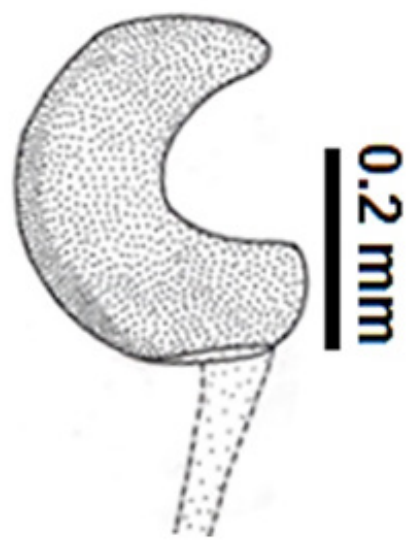

b

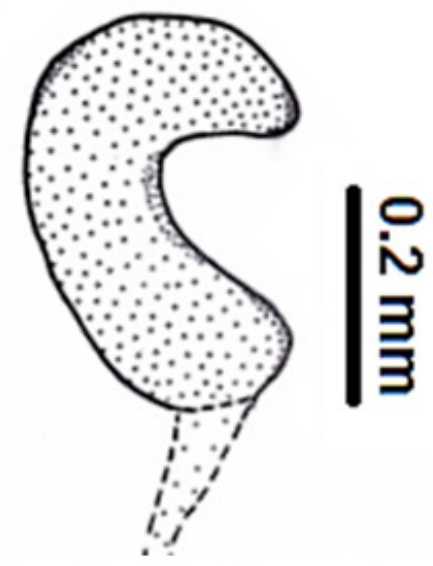

Figure 2. Spermatheca a) C.flavimana b) C.colchica.

of this, C. humeralis lateral lobs have the narrow form in basal and widen distinctively towards medial and gets narrow from distal to apical.

When female spermatheca belonging to Cortodera colchica and C. flavimana species are compared it is seen that body parts of both of them resemble to " $c$ ". However the letter " $c$ " of C. colchia is wider and longer in the upper arm compared to lower arm and apex of the body is more circular while in C. flavimana; the arms of letter " $\mathrm{C}$ " is equal to each other in length and width and apex of body is narrower and sharp, in this sense $C$. colchia differs from $C$. flavimana.

It would be possible by examing the other species of genus, the features using for species identification that explained above are genus features or not. 


\section{References}

1. Adlbauer, K., Neueszur Taxonomie und Faunistik der Bockkäferfauna der Türkei ( Coleoptera: Cerambycidae). Entomofauna 9 (1988) 257-297.

2. Ehara, S., Comparative Anatomy of Male Genitalia in Some Cerambycid Beetles. Journal of the Faculty of Agriculture, Hokkaido University Series 6, Zoology 12 (1954) 61-115.

3. Hernández, J. M., Estudio de la genitalia femenina del género Agapanthia Serville, 1835 en la Península Iberica y su aplicación taxonómica (Coleoptera, Cerambycidae,Lamiinae). Boletim da Sociedade Portuguesa de Entomologia 2 (1992) 499-508.

4. Hernández, J. M. and Ortuño, V. M., Estudio de la genitalia femenina en las especiesibéricas del género Rhagium Fabricius, 1775 (Coleoptera: Cerambycidae, Lepturinae). Boletín de la Asociación Española de Entomología 21 (1997) 61-67.

5. Hubweber, L. and Schmitt, M., Parameres-Similarities and Differences in Chrysomelidae and Cerambycidae (Coleoptera). Bonner Zoologische Beiträge 54 (2005) 253-259.

6. Hubweber, L. and Schmitt, M., Differences in genitalia structure and function between subfamilies of longhorn beetles (Coleoptera: Cerambycidae). Genetica 138 (2010) 37-43.
7. Löbl, I. and Smetana, A. (Editor). 2010. Catalogue of Palaearctic Coleoptera, Vol. 6. Chrysomeloidea. Stenstrup. ApolloBooks. 924 pp.

8. Önalp, B., Taxonomic researches on Agapanthia Serville, 1835 species (Coleoptera, Cerambycidae: Lamiinae) I. H. Ü. Eğitim Fakültesi Dergisi 3 (1988) 257-295.

9. Önalp, B., Systematic researches on Dorcadion Dalman, 1817 species in Turkey (Coleoptera, Cerambycidae: Lamiinae) I. H. Ü. Eğitim Fakültesi Dergisi 5 (1990) 57-102.

10. Önalp, B., Systematic researches on Dorcadion Dalman, 1817 species in Turkey (Coleoptera, Cerambycidae: Lamiinae) II. H. Ü. Eğitim Fakültesi Dergisi 6 (1991) 191-227.

11. Özdikmen, H., The Longicorn Beetles of Turkey (Coleoptera: Cerambycidae) Part IV Mediterranean Region. Munis Entomology\&Zoology 6 (2011) 6-145.

12. Sama, G. 1982. Contributo allo studiodei Coleotteri Cerambycidaedi Grecia e Asia Minore Fragmenta Entomologica. 16 (1982) 205-227.

13. Tuxen, S. L. (Editor). 1970. Taxanomist's Glossary of Genitalia in Insects. Munksgaar, Copenhagen, Denmark. 359 pp. 